\title{
INCAPACITY FOR WORK OF EMPLOYEES OF THE SELECTED METALLURGICAL PLANT RELATED TO AGE
}

\author{
Milena Menzlováa, Eva Smelikováb, Milan Kekac
}

a University of Ostrava, Czech Republic
${ }^{b}$ Metallurgical Health Insurance Company Ostrava, Czech Republic
${ }^{c}$ Czech Social Security Administration, Ostrava Office, Czech Republic

Received: June 15, 2003; Accepted in revised form July 7, 2003

Key words: Health status/ Dorsopathy/ Age dependence/ Occupational medicine

Evaluation of the health state of employees in relation to the working environment is one of the main tasks of occupational medicine. The specified results represent a part of a methodically oriented project which was focused on evaluation of:

- age structures of employees in the metallurgical plant being monitored in comparison with the age structure in the whole region,

- evaluation of the health status of employees in the plan by means of absolute and relative indicators of morbidity and even their dependence on age.

The analysis was carried out during three successive years in approximately 10000 employees of a metallurgical plant. The selected six groups of diagnoses represented from $40 \%$ to $50 \%$ of all employees suffering from a disease. Particularly the following diagnoses according to the International Classification of Diseases were involved there: I10-I15 (hypertensive disease), I20-I25 (ischaemic heart disease), J00-J06 (acute infections of upper respiratory airways), K20-K31 (diseases of oesophagus, stomach and duodenum), M15-M19 (arthroses) and M50-M54 (dorsopathies).

The age structure of employees related to men and women was considerably statistically significantly different from the age structure of the region.

From the economic point of view on incapacity for work, we consider the number of days of absence from work for the reason of the disease as an indicator with the highest informative value. We noted two dominative maxima in men and women for this characteristic. A proportion of patients with acute infections of upper respiratory airways ranged from $40 \%$ to $50 \%$ out of total cases of diagnoses we have followed up, the highest number of patients was in men aged 20-24 with a subsequent significant decrease. We did not find any noticeable dependence on age for this diagnosis in women, only a slight increase in older age categories was evident. Dorsopathies are the second most frequent group; they were from 30 to $38 \%$ out of all monitored diseases. The age dependence was evident especially in women aged $40+$. Considering duration of incapacity for work and its repeatability, dorsopathies seem to be the most relevant health problem in employees in heavy industry, and especially in women.

The participation of the remaining four selected groups of diseases is relatively low. Both in men and women, the hypertensive disease ranged from $1.9 \%-3.7 \%$, ischaemic heart disease from $0.4 \%-6.5 \%$, diseases of oesophagus, stomach and duodenum from 5.3\%-9.0\% and arthroses from $4.7 \%-6.8 \%$ in three years in question.

\section{INTRODUCTION}

A level of further human existence depends on one's health. It is an outcome of numerous factors; a part of these factors is changing together with a social development. Recognition of regularities of their mutual relationships demands a certain level of generalization. Thereafter, a subject of the study is not a human being as an individual, but it consists in groups of people defined in a various way within the frameworks of which events of mass character are investigated.

It is generally assumed that every single population is characterized by a certain level of health. This level is dependent on a great number of known quantities, but also unknown ones for the time being. An influence of age belongs among the most marked relationships.

It is also problematic to express this level of health in some exact manner. That is why the health is generally defined using its negative attribute, i.e. a disease. And as far as we follow this completely non-preventive interpretation, i.e. an assessment of health through the mediation of a disease, we will have problems with its measurability.

The most common methodical approaches to these problems differ one from the other in economic expenses and informative value. Data analysis from health 
statistics linked up to the International Classification of Diseases ${ }^{12}$ is most frequently used for practical needs of health management.

This method was also used in the submitted paper aimed at description of actual health state of employees in a comparatively large metallurgical plant. At present a transformation of production technologies is being performed there and, together with this activity, even changes in the number and structure of employees are being planned. The results should serve as grounds for purposefully oriented measures focused on prevention of a selected group of diseases including appropriate distribution of financial subsidies.

\section{METHODOLOGY}

\section{Type of the study}

Retrospective analysis of the chosen characteristics of incapacity for work in the years 1997-1999 in the selected groups of diagnoses.

\section{Selection of the followed up groups of diagnoses}

The selection was led by an effort to register groups of diagnoses that belong among more relevant ones either from their occurrence or their health consequence point of view. The carried-out analysis was applied to the following six groups of diseases, as expressed by abbreviations of the International Classification of Diseases from 1992 (ref. ${ }^{12}$ ):

- Dg. I10-I15 - hypertensive disease

- Dg. I20-I25 - ischaemic heart disease

- Dg. J00-J06 - acute infections of upper respiratory airways

- Dg. K20-K31 - diseases of oesophagus, stomach and duodenum

- Dg. M15-M19 - arthroses

- Dg. M50-M54 - other dorsopathies

Based on the previous analysis of morbidity rate of inhabitants of three districts, we found that the above mentioned selected diagnoses comprise from 45 to $48 \%$ of all notified incapacities for work.

\section{Group selection}

The subject of the analysis consisted in a total selection of men and women employed during 1997-1999 in a particular metallurgical plant. At the same time these employees are insured persons of the Metallurgical Health Insurance Company which assigned the presented enquiry. According to the conducted investigation, currently $81.2 \%$ of all employees from the mentioned plant are insured in this insurance company.

Information on the age structure of inhabitants from the North-Moravian Region in comparable years was taken over from a Year Book of the Czech Statistical Office.

Data source and protection against misuse of personal and health data

A detailed database of the health insurance company is administrated by professionals qualified in data management and they went through training in data protection. For the purpose of this study, the data of individual insured clients were grouped according to the given instructions. That measure made their further processing easier and at the same time thwarted their contingent misuse by other users. The database conception including its protection went through an audit of the authorized person from the Ministry of Health of the Czech Republic.

\section{Data processing}

Descriptive statistics, analysis of contingence tables and a non-parametric Kolmogorov-Smirnov test were used for a statistical data evaluation. Results were processed using Microsoft Excel and EPI-INFO 6 software. Details are introduced at appropriate places in the text.

\section{RESULTS}

Figures related to employees for individual years are stated in Table 1. Due to the character of production, the number of employed women is substantially lower in comparison with the number of men. From the table there is also obvious a permanent decrease in the number of employed men and women during three presented years.

The age structure of employees is visible from Figures 1 and 2. Both figures show a very similar age structure during the three observed years. However, the age structure of employed men and women in the monitored plant is mutually highly statistically significantly different (a Kolmogorov-Smirnov test $\mathrm{P}=0.0000)$. The

Table 1. The absolute numbers of employees in the followed up period.

\begin{tabular}{|l|c|c|c|c|c|c|c|c|c|}
\hline \multirow{2}{*}{ Age } & \multicolumn{3}{|c|}{ Women } & \multicolumn{3}{c|}{ Men } & \multicolumn{3}{c|}{ Total } \\
\cline { 2 - 11 } & 1997 & 1998 & 1999 & 1997 & 1998 & 1999 & 1997 & 1998 & 1999 \\
\hline Total & 2397 & 2209 & 2054 & 8523 & 8161 & 7742 & 10920 & 10370 & 9796 \\
\hline
\end{tabular}




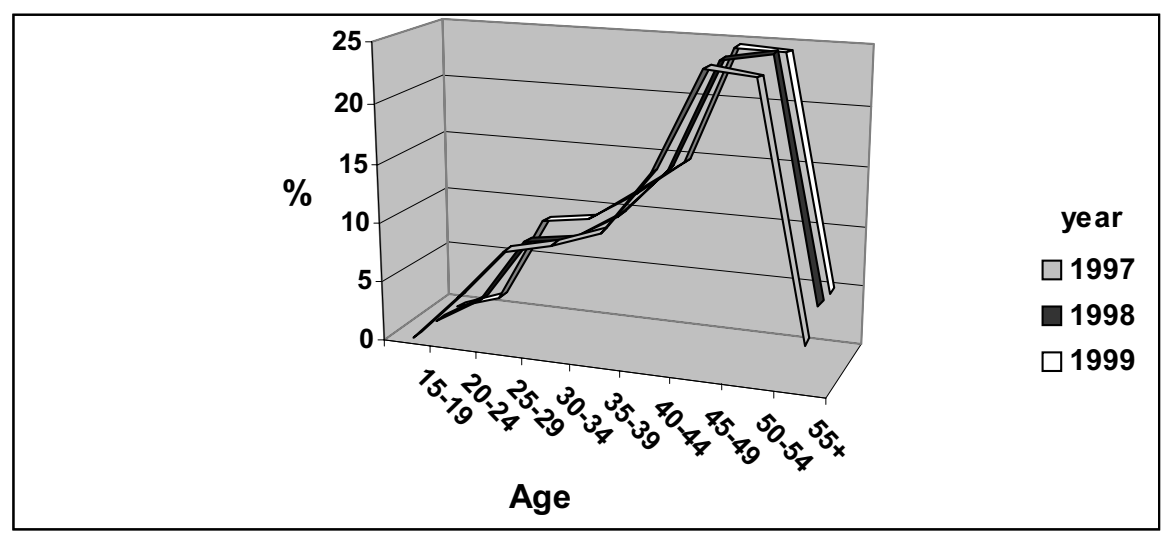

Fig. 1. The age structure of the selected metallurgical plant in the years in question.

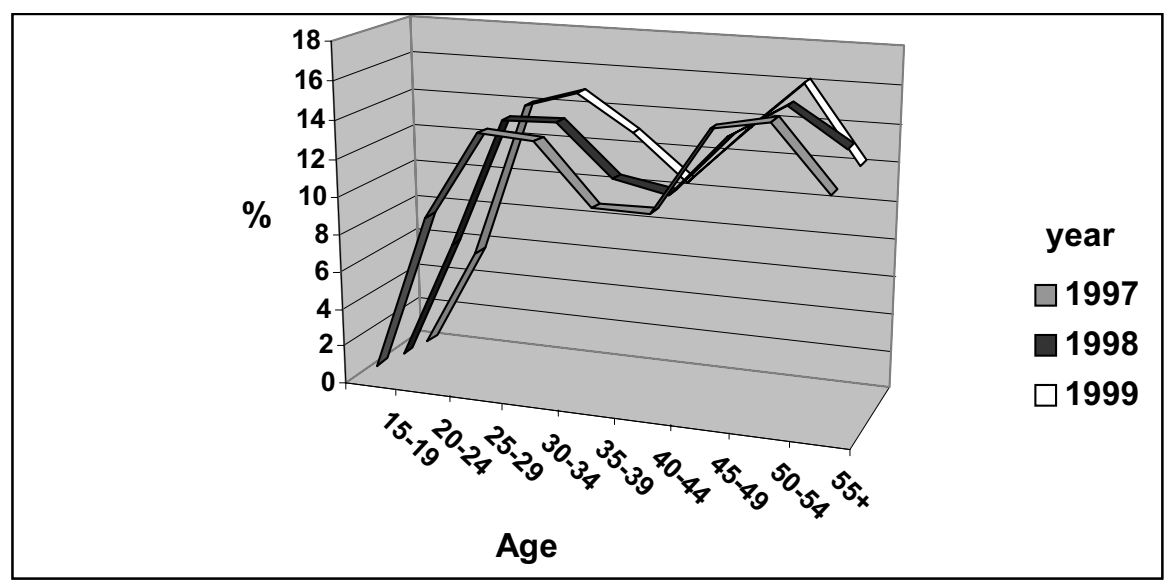

Fig. 2. The age structure of men of the selected metallurgical plant in the years in question.

age distribution of woman and men in the monitored plant is also considerably statistically significantly different from the age structure of the whole region (a Kolmogorov-Smirnov test, $\mathrm{P}=0,0000$ ), where the distibution of frequencies in the productive age is equal and without any major variations.

As for morbidity indicators, we had at our disposal especially absolute indicators, i.e. figures given in absolute numbers for the defined time period. Especially three basic characteristics were involved there, namely: the number of cases with incapacity for work (IFW), the number of days of incapacity for work (DIFW) and the number of diseased persons, i.e. the number of notified birth certificate numbers $(\mathrm{BCN})$. Next relative numbers were derived from these $\mathrm{BCN}$.

The company accountant will be especially interested in how many persons are missing daily at their workplaces due to their incapacity for work. From the spectrum of diagnoses and their average duration, it is also possible to derive the incapacity for work during the nearest following period. From a long-term prospect standpoint it is possible to specify priorities of preventive health programmes including a work-out of their strategy in individual fields ${ }^{2,6}$. From this viewpoint, figures concerning days of absence related to acute upper respiratory airways infections (Dg. J00-J06) and dorsopathies (Dg. M50-M54) shown in Figures 3 and 4 are especially interesting. Both mentioned items significantly prevail among six selected groups of diagnoses. Using the applied form of presentation, morbidity in men with the first group of diagnoses is always slightly lower than that in women. In total, a proportion of days of IFW because of this diagnosis range from $40 \%$ to $50 \%$ from all the followed up diagnoses. On the other hand these groups of diagnoses have the shortest average duration of IFW from all the followed-up diagnoses. In the respective plant, slightly shorter average duration of IFW is in men than in women with these diagnoses (15.6 and 17.6 days, respectively).

Dorsopathy belongs among the group of diseases with a somewhat longer duration. The number of days of work absence with respect of this diagnosis represents another maximum of both circle diagrams, i.e. both in men and in women. A proportion of days of work absence because of IFW ranges from $30 \%$ to $38 \%$ and it is again slightly lower in men than in women.

A participation of other four selected groups of diseases is relatively low. Both in men and women, the hypertensive disease ranges from $1.9 \%$ to $3.7 \%$ in the stated three years, ischaemic heart disease from $0.4 \%$ to $6.5 \%$, diseases of oesophagus, stomach and ulcer from $5.3 \%$ to $9.0 \%$ and arthrosis from $4.7 \%$ to $6.8 \%$. 


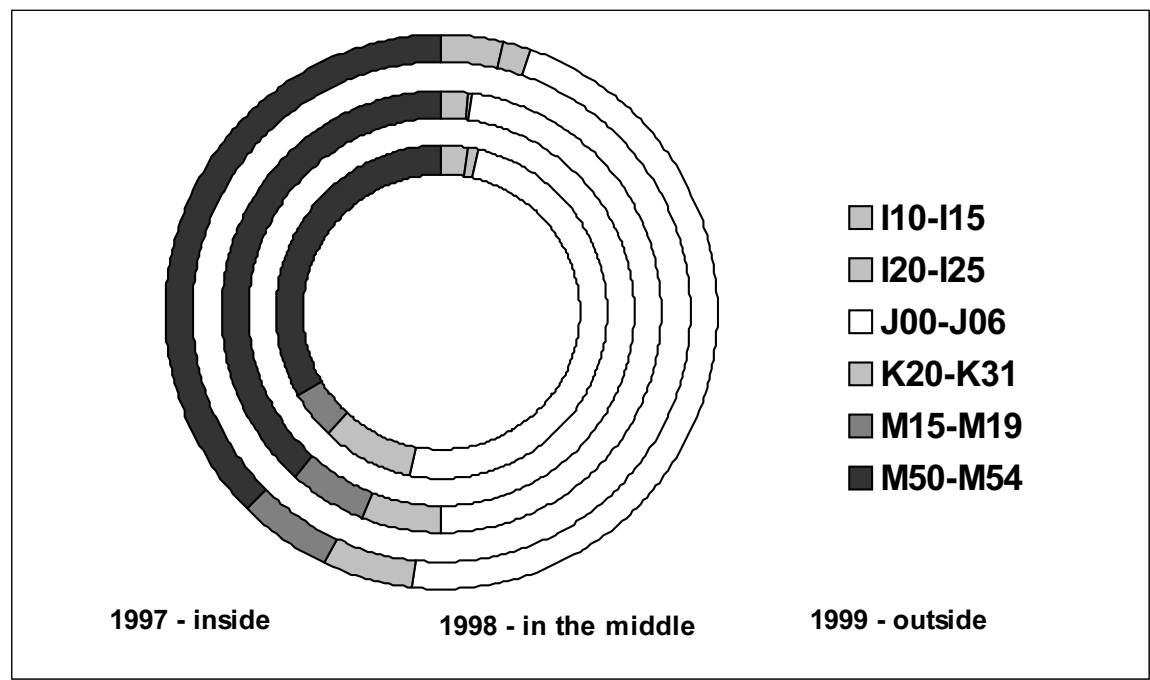

Fig. 3. The proportion of the selected diseases by days of absence from work in women.

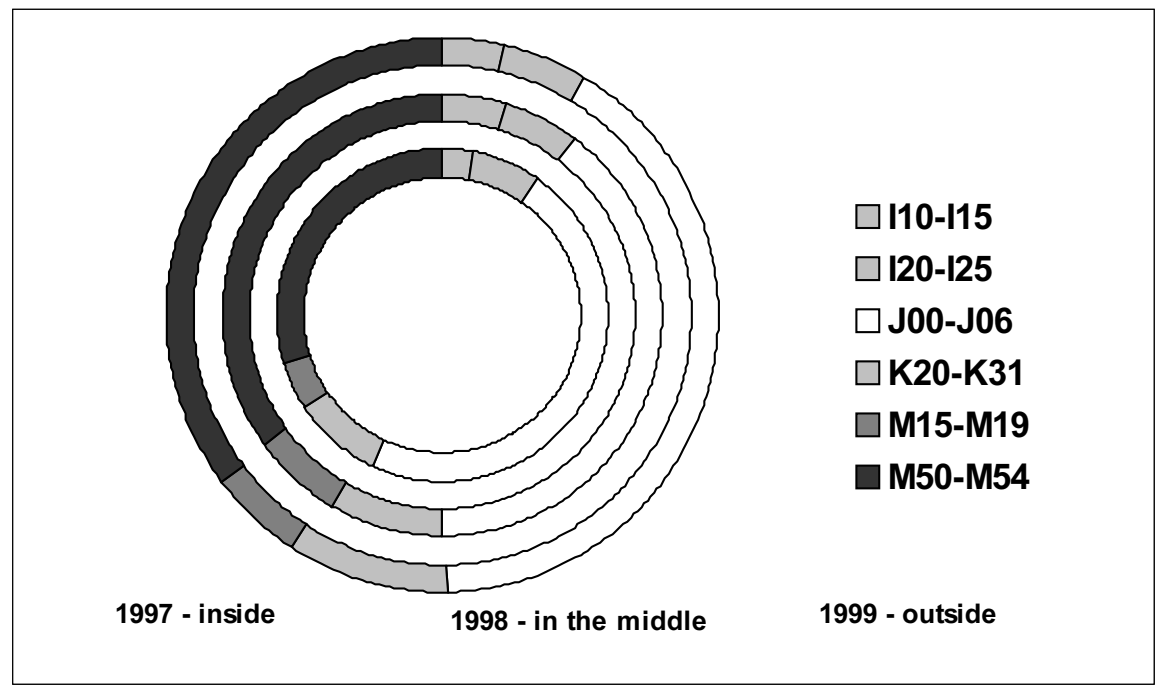

Fig. 4. The proportion of the selected diseases by days of absence from work in men.

Acute infections of the upper respiratory airways and dorsopathies seem to represent most relevant problems of the introduced six selected groups of diagnoses. Figures 5 and 6 show their relation to age. From Figure 5 it is obvious that the marked increase in the number of days of work absence due to dorsopathies is related to increasing age. This increase is noticeable especially from the age of $40+$. The number of days of work absence due to infections of the upper respiratory airways rather slightly increases with the age in women. Frequencies of similar diseases in men (and especially their dependence on age, see Figure 6) are considerably different. The number of days of work absence due to dorsopathies in the age of $40+$ is approximately double in women than in men. This inter-sex comparison has an opposite trend in the case of the upper respiratory airways infections. It means a marked prevalence of these affections in men of younger age category namely at the age of 20-24 years.

\section{DISCUSSION}

Preferences of various methods of the health state observation are traditionally different in various countries. While studies in the form of an interview prevail in western countries $5,8,9,10$, the utilization of results of preventive medical check-ups and analysis of health statistics prevail in the Czech Republic ${ }^{7}, 11$. Similar tradition exists also in some countries of Eastern Europe ${ }^{1,2}$. Generally, methodical procedures have not been standardized up to this time to make possible a comparison of results not only in the worldwide scale ${ }^{4}$, but also in our republic 5 . The procedures for processing the health statistics, which have a long-time tradition in this country, seem to be the most standardized. The data processing connected with incapacity for work is also one of their variants. Even if the data acquisited in this way reflect first the employees population they have a reference to the considerable part of population in working age and thereafter they can become a valuable 


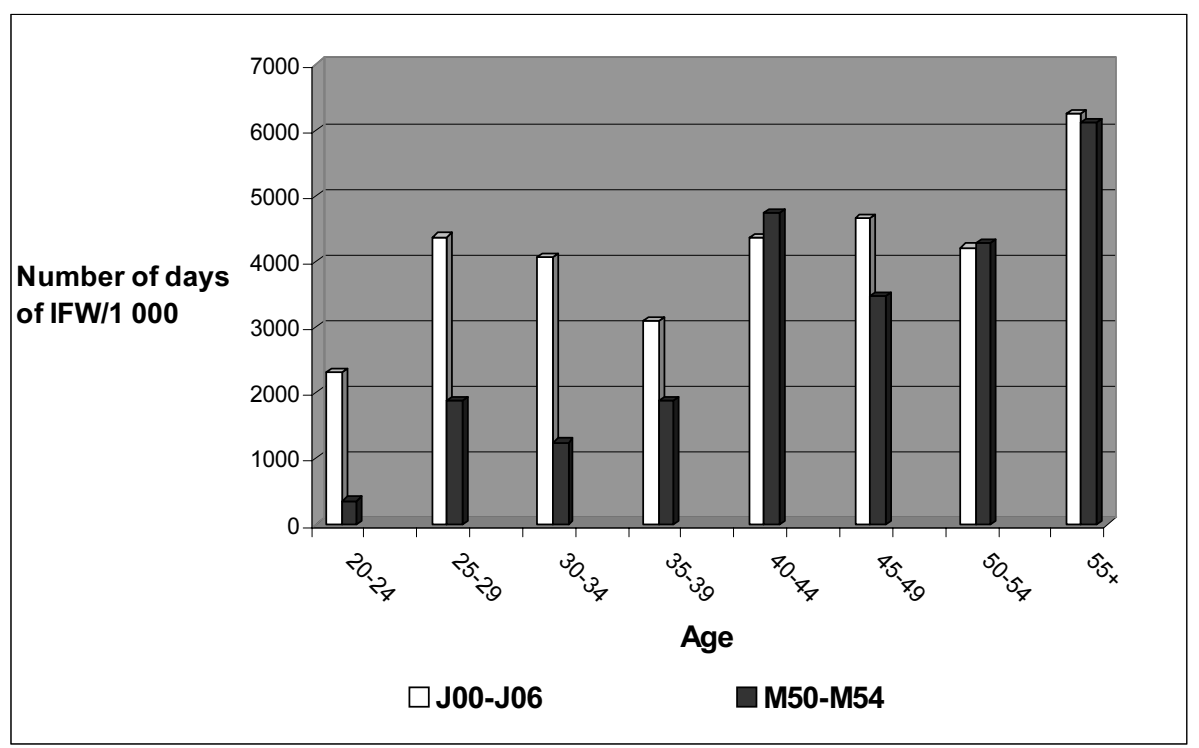

Fig. 5. The most frequent diseases in women related to age.

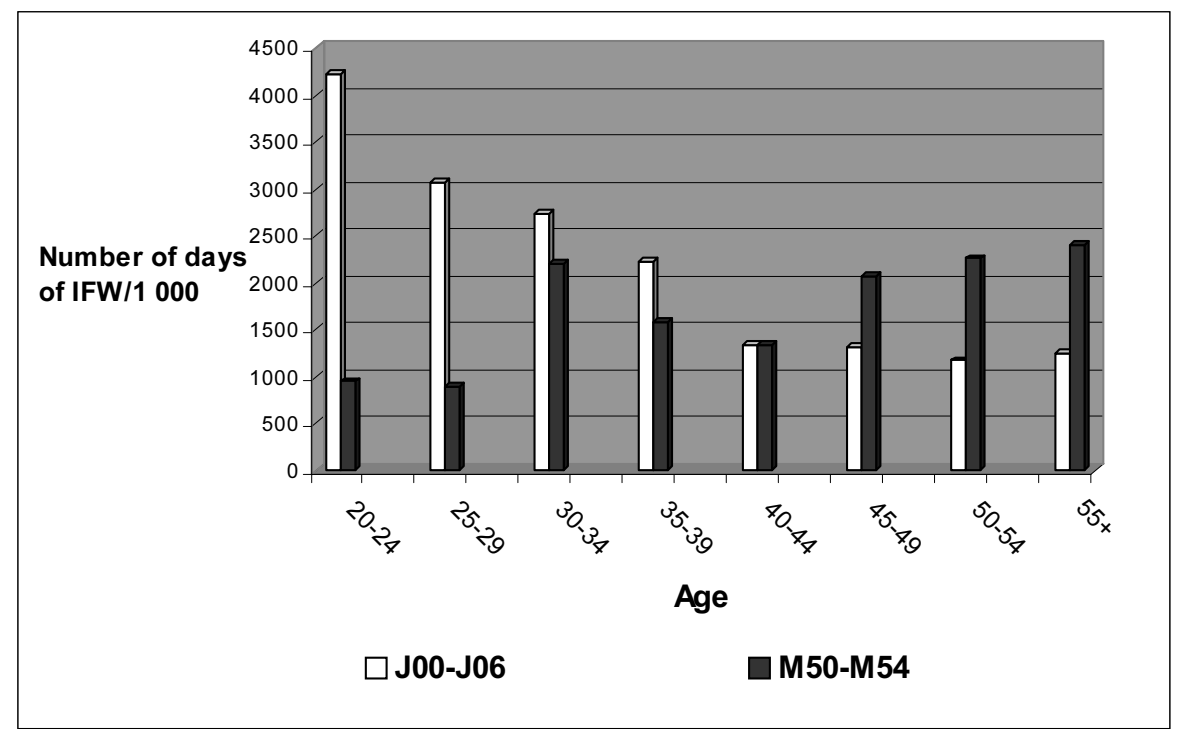

Fig. 6. The most frequent diseases in men related to age.

strategic tool ${ }^{6,10}$. There is also a suitability of their purposeful use in occupational medicine. An acquisition of reference values in a sufficiently large group represents grounds for studies oriented in such way. One of the most extensive study during the recent fifteen years ${ }^{3}$ brought results from 130000 inhabitants, which represented $1.3 \%$ of the population of the Czech Republic. However, results that are extensive and interesting because of their sorting and processing do not sufficiently correspond with our intentions, namely in the field of occupational medicine. For example, scaling of age according to the rules of WHO MONICA program has become familiar during recent years in our country. Uneven scale is not convenient for the needs of occupational medicine and it does not also enable to use some statistical tests. Therefore, we cannot sufficiently compare the results of health complaints of the Czech popu- lation from the year 1996; ; however, general trends seem to be similar. For example, chronic vertebral diseases in men are not so markedly related to the age than those in women.

Considering chronic vertebral diseases and frequency of involvement, just dorsopathies are of greatest importance for working capacity among employees in the plant monitored in our study. It goes especially for women older than 40 . This conclusion is emphasized by riskiness and physically demanding work in metallurgy. Moreover, this critical period coincides with the period of the largest age accumulation of women.

The main purpose of the project was to work out the methodology for an evaluation of the health state which could be used especially in occupational medicine. The absolute and relative indicators of morbidity under elaboration in a relatively large group of employees in a heavy 
industry can be prospectively used as reference values. For the time being we have considered the mentioned specific results as the means of visual application up to this time.

A choice of certain characteristic of the health state depends first on the goal we follow. An advantage of simple statistical characteristics consists in their simple interpretation; however, only some of them are accessible to statistical analysis.

\section{ACKNOWLEDGEMENT}

This study was supported by Grant No. 4883-3 from the Ministry of Health of the Czech Republic.

\section{REFERENCES}

1. Borokhov DZ, Petrov PP, Kulmankhanov AV, Novikov AV. (1990) Methodological approaches to the evaluation of the effects on environmental pollution on morbidity of the population. Sov Zdravookhr 5, 23-7.
2. Brushlinskaia LA. (1968) The value of morbidity statistics in assessing the health of the population. Gig Sanit 33, 3-6.

3. Harant J, Mazánková V. (1989) Rozbor př́ičin pracovní neschopnosti a úmrtnosti středních věkových skupin obyvatelstva ČSSR. Čs Zdrav 37, 260-73.

4. Harant J. (1990) Metodické př́ístupy k šetření celkové nemocnosti obyvatel v zahraničí. Čs Zdrav 38, 340-7.

5. Harant J. (1990) Metodické přístupy k šetření celkové nemocnosti v ČSFR. Čs Zdrav 38, 334-9.

6. Harant J. (1988) Včerejší čísla pro zítřejší rozhodování. Zdrav Nov 37, 3.

7. Holčík J, Sklář B. (1998) Zpráva o průběhu a závěrech semináře Efektivita zdravotní prevence zaměstnanců v podmínkách závodů. Pracov Lék 4, 187-8.

8. Holčík J. (1977) K problematice souhrnného měření zdravotního stavu obyvatelstva. Čs Zdravot 11, 456-63.

9. Mazánková V. (1989) Analysis of morbidity in the Czech population. Čes Zdrav 37, 193-7.

10. Medina E, Kaempffer AM, Cumsille F, Medina R. (1987) Morbidity and medical care surveys as a method of analyzing health status. Bol Oficina Sanit Panam 6, 594-605.

11. Menzlová M, Sklář B, Smelíková E, Keka M. (2001) Pracovní neschopnost jako charakteristika zdravotního stavu výběrového souboru. Sborník z XXVI. Pachnerových dnů v Rožnově p. R., 16-17.

12. Mezinárodní klasifikace nemocí /International classification of diseases/, Revision 10, Edition 2, Praha 1992, p. 646. 